4. Communication from the Commission to the European Parliament, the Council and the Committee of the Regions. Towards a general policy on the fight against cyber crime. COM(2007) 267 final. Brussels, 22.5.2007. Retrieved from https://eur-lex.europa.eu/LexUriServ/LexUriServ.do?uri=COM:2007:0267: FIN:EN:PDF [in English].

5. Communication from the Commission to the European Parliament, the Council, the European Economic and Social Committee and the Committee of the Regions on Critical Information Infrastructure Protection «Protecting Europe from large scale cyber-attacks and disruptions: enhancing preparedness, security and resilience». COM(2009) 149 final. Brussels, 30.3.2009. Retrieved from https://eur-lex.europa.eu/LexUriServ/ LexUriserv.do?uri=COM:2009:0149: FIN:EN:PDF[in English].

6. Challenges to effective EU cybersecurity policy Briefing Paper March 2019 (2019). European Union [in English].

7. Shared Vision, Common Action: A Stronger Europe. A Global Strategy for the European Union's Foreign and Security Policy. June 2016 (2016). Brussels [in English].

8. The year in review. From January 2019 to April 2020 (2020). ENISA Threat Landscape [in English].

9. Main incidents in the EU and worldwide. From January 2019 to April 2020 (2020). ENISA Threat Landscape [in English].

10. Zakonodavstvo ta strategii y sferi kiberbezpeky krayin Yevropeyskogo Soyuzu, SSHA, Kanady ra inshyh. Informatsiyina dovidka, pidgotovlena Yevropeyskym informatsiyino-doslidnytskym tsentrom na zapyt narodnogo deputata Ukrayiny (2016). Kyiv: Infotsentr, Yevropeyskyy informatsiyno-doslidnytskyy tsentr, Laboratoriya zakonodavchyh initsiatyvs [in English].

11. Cybersecurity. State of federal it report. Public release version 1.0. Policy Papers. Retrieved from https: $/ /$ www.cio.gov/assets/resources/sofit/02.05. cybersecurity.pdf [in English]

12. Holslag, J. (2014). The Power of Paradise. How Europe Can Lead the Asian Century [in English].

13. Joint communication to the European Parliament and the Council. Resilience, Deterrence and Defence: Building strong cybersecurity for the EU. Brussels, 13.92017. JOIN(2017) 450 final. Retrieved from https:/ eur-lex.europa.eu/legal-content/en/TXT/?uri=CELEX\%3A52017JC0450 [in English].

14. Shaping Europe's digital future. Policy. Cybersecurity. European Commission. Retrieved from https: ec.europa.eu/digital-single-market/en/cybersecurity [in English].

Стаття надійшла до редакції 12.02.2021.
DOI:10.35774/app2021.01.011

УДК 343.971 (477)

\section{Тетяна Подковенко,}

кандидат юридичних наук, дочент кафедри теорії та історії держави і права Західно-

украінського наиіонального університету

\section{НАЦІОНАЛЬНА БЕЗПЕКА УКРАЇНИ: АКСІОЛОГІЧНИЙ}

\section{ТА ПРАВОВИЙ АСПЕКТИ}

У статті представлений філософсько-правовий аналіз поняття наиіональної безпеки. Розкрито підходи вітчизняних та зарубіжних науковиів до поняття начіональної безпеки. Визначено, що у сучасних умовах проблема якісного забезпечення національної безпеки, розробка системної державної політики захисту націо нальних інтересів та належних механізмів ї̈ реалізаиії є надзвичайно актуальною. Наиіональна безпека є одним із ключових елементів функиіонування держави, що забезпечуе не просто можливості існування, а також належний розвиток та свободу реалізаиії наиіональних інтересів та цінностей. У статті проаналізовано законодавство Украӥни про наиіональну безпеку в аспекті відображкення та захисту загальнолюдських цінностей. ключові спова: безпека, наиіональна безпека, забезпечення національної безпеки, національні інтереси, загальнолюдські цінності, політика національної безпеки.

\section{Подковенко Т.}

(1)

В статье представлен философско-правовой аналіз понятия наииональной безопасности. Раскрыто подходы отечественных и зарубежных ученых к понятию национальной безопасности. Определено, что

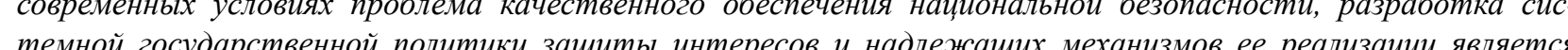

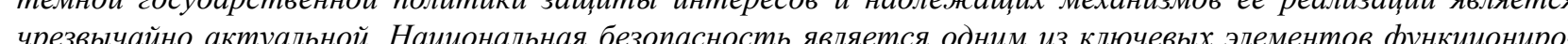

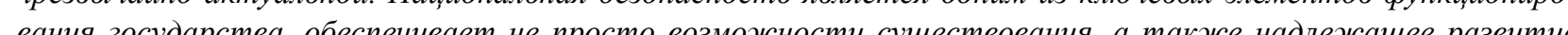
u croбody pe Украины о национальной безоласности в аспекте отражения и заиитты общечеловеческих иенностей.

Ключевые слова: безопасность, начиональная безопасность, обеспечение национальной безопасности, национальные интересы, общечеловечиские ченности, политика национальной безопасности.

\section{Podkovenko T.}

National security of Ukraine: axiological and legal aspects

The article presents a philosophical and legal analysis of the concept of national security. The approaches of domestic and foreign scientists to the concept of national security are revealed. It is determined that in modern condition the problem of quality national security, the development of a systematic state policy to protect national interests and appropriate mechanisms for its implementation is extremely relevant. National security is one of the key elements of the functioning of the state, which provides not only the possibility of existence, but also the proper development and freedom to realize national interests and values. The article analyzes the legislation of Ukraine on national security in terms of reflection and protection of universal values.

The approaches to understanding national security analyzed in the article only confirm the fact that the universality of the content of national security determines the universality of the values it reflects and the protection of which should be aimed at public policy. This is a special state of protection of the individual, society and state from internal and external threats, which ensures the realization of constitutional rights and freedoms of citizens, decen quality and standard of living, sovereignty, independence, state and territorial integrity, sustainable socio-economi development. The complexity and systematization of state policy, its focus on the protection of universal values of modern civilization should be the key to further development of our society.

Keywords: security, national security, ensuring national security, national interests, universal values, national security policy.

Постановка проблеми. У сучасному світі поняття безпеки займає особливе місце у всіх процесах життедіяльності людини: політичних, економічних, соціальних, технічних, біологічних та інших. Про

\section{() Тетяна Подковенко, 2021}


це свідчать і події останніх років, що пов'язані із загостренням проблем світової безпеки та про доволі неоднозначний вплив процесів глобалізації на розвиток різних країн. Як стверджують науковці, за таких

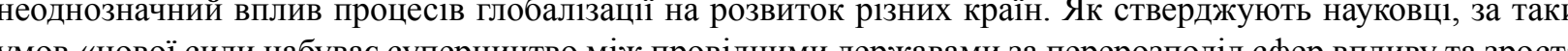
умов,

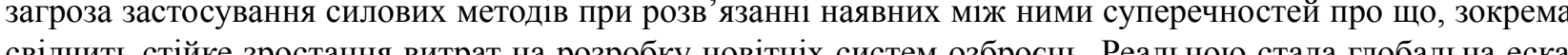

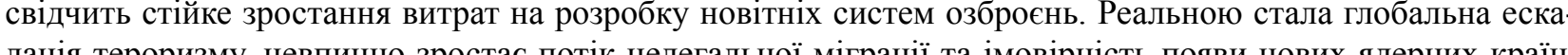
лація керорзи, нар набувас зароз спостерігаємо загострення різного роду суспільно-політичних та соціально-економічних проблем, які доволі часто трансформуються у збройні конфлікти, протистояння різних соціальних груп, ескалація яких стає реальною загрозою для міжнародного миру та стабільності подальшого розвитку.

Саме тому, у сучасних умовах проблема якісного забезпечення національної безпеки, розробка системної державної політики захисту національних інтересів та належних механізмів ії реалізації є надзвичайно актуальною. Ця проблема привертає особливу увагу державних і громадських діячів, науковців різних галузей та пересічних громадян України. Як зазначає В.Копанчук, «багатоаспектність і комплексність ціеї проблеми зробили ії предметом дослідження фахівців практично всіх галузей наукового знання: техніки, філософії, соціології, права, психології, економіки, математики, екології, біології, охорони здоров' та ін. Ефективне державне управління національною безпекою передбачає систематизацію, деталізацію, класифікацію, визначення закономірностей, взаємозв' язку та внутрішньої іерархії між ними, а також основними поняттями, які використовуються при дослідженні національної безпеки» [2, с.2].

Формування та реалізація в Україні державної політики національної безпеки є чи не найголовнішою проблемою ефективного управління суспільством, що трансформується. Українська політична практика засвідчує, що технологія реалізації доктрин, стратегій, концепцій і програм державної політики у сфері національної безпеки об'єктивно має інтегрувати всі компоненти політичної активності держави базуватися на грунтовних теоретичних засадах та історичному досвіді.

Сьогодні теорія національної безпеки проходить етап активного формування та динамічного розвитку. Пошук надійних теоретичних засад організації системи стратегічного планування у сфері національної безпеки потребує ії розгляду з погляду застосування найзагальніших політико-правових метолів нальст безк спрямованих на дослгення найвишого рівня наніональної безгеки [3,c. 11].

Національна безпека є одним із ключових елементів функціонування держави, що забезпечує не просто можливості існування, а також належний розвиток та свободу реалізації національних інтересів. Саме тому, концепція державної політики у сфері національної безпеки України має мати комплексний та системний характер і передбачати координашію зовнішніх та внутрішніх складових економічної, сошіальної, екологічної, науково-технологічної, культурної, воєнної, інформаційної політики держави.

Аналіз останніх досліджень і публікацій. Зростання різноманітних глобалізаційних викликів сучасності, які створюють небезпечні умови існування та стабільного функціонування людської цивілзації, державних утворень, суспільства, господарюючих суб'єктів, особистості, активізували спалах інтересу до проблематики забезпечення безпеки на усіх її ієрархічних рівнях з боку владних структур, наукових діячів та громадськості загалом. Як бачимо проблема забезпечення національної безпеки та здійсненн ефективного публічного управління в сфері національної безпеки України $€$ надзвичайно актуальною. Питанням забезпечення національної безпеки України присвячена значна кількість наукових досліджень втчизняних фахівців: В. Авер'янова, С.Андреєва, О. Бандурки, А. Басова, О. Борисенко, Ю. Битяка, О. Власюка, О.Давидюка, А.Дегтяра, С. Домбровської, А. Калюжного, В. Ліпкана, Ю.Павлютіна, Є.Романенка, С Руснак, В. Садкового, Г. Ситника та ін.

Виклад основного матеріалу. У сучасному науковому знанні поняття «безпека» $є$ одним із найскладніших та неоднозначних. Зумовлено це, в першу чергу, багатоаспектністю цього терміну, його довоскладним змістовним наповненням та міждисциплінарним характером. Проблематика безпеки апріорі займає статус найвищого пріоритету в політиці держави, тому вона виступає предметом дослідження науковців різноманітних сфер діяльності: філософів, політологів, правознавців, економістів, психологів, представників органів державної влади і т.д., які вбачають у ній «визначальний чинник у збереженні, стійкому функціонуванні і стабільному розвиткові».

Забезпечення національної безпеки є одним із основних завдань держави. Про його важливіст найкраще свідчить той факт, що у багатьох наукових дослідженнях та стратегічних документах національна безпека визначається як «найвища цінність», «національна мета», «вища ціль державної політи- ки», «найвища екзистенціальна цінність», «національна цінність». Водночас національна безпека має чітко сформовану правову базу, яка через доволі комплексний характер питання регулюється кількома десятками нормативно-правових актів. Таким чином, юридичні норми, визначені в доктрині юридичних наук як право національної безпеки, складають акти національного права, а також акти міжнародного права.

Варто зазначити, що ще у XVII - XVIII століттях практично в усіх країнах було визначено головну мету держави - забезпечення загального блага та безпеки суспільства [4, с. 56]. У зв'язку з цим термін «безпека» набув нового значення і означав «стан, ситуацію спокою, що виникає в результаті відсутності реальної небезпеки (як фізичної, так і моральної), а також наявність матеріальних, економічних, політичних умов, відповідних органів та організацій, що сприяють створенню такої ситуації» [5, с. 10].

Безпека - $є$ однією з тих сфер, яка має особливе значення як для держави, яка витупає в якост особливої публічної інституції, для суспільства в цілому, так і для окремих його членів, і тому її варто розглядати як ключовий елемент категорії загальне благо. Загальне благо $€$ основою суспільного порядку та політичного устрою демократичноі правовоі держави, і відповідно виступає метою діяльності державних органів влади. І хоча поняття загального блага має яскраво виражений філософський аспект, його ключов прояви знаходять своє відображення в основних сферах суспільного життя, таких як право, економіка політика.

Загальним благом варто визначати державу, а саме ії незалежність, міжнародний авторитет, економічне процвітання та безпеку, а безпека була і залишається однією з найважливіших цілей держави. Однією 3 найбільших проблем, які пов'язані з тлумаченням сутності загального блага - це його здатність, відображати різноманітні і доволі складні соціальні процеси, в яких воно виникає і функціонуе.

Загальне благо - це ідеал правової держави, у якій людина, ііі права та свободи складають дійсно найвищу соціальну цінність. I якщо неможливо досягти ідеального функціонування суспільства, однак це не причина щоб не прагнути до ідеальної держави та вдосконалювати інституції, які відповідальні за повноту реалізанії ліберальних, демократичних шінностей, Ніщо не звільняс нас від обов'язку прагнення до ідеальної держави та ідеальної свободи, справедливості, відповідальності.

Безпеку варто розглядати в якості тієї універсальної цінності, яка стосується нескінченої кількості суб'єктів, хоча найбільше значення має безпека особистості, соціальної групи і держави. До основних

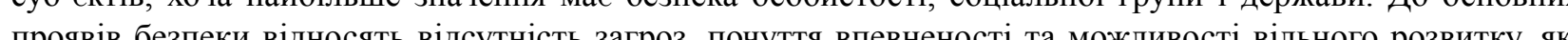

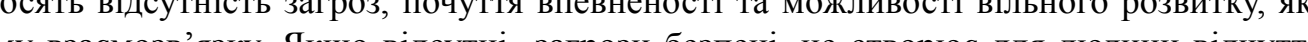

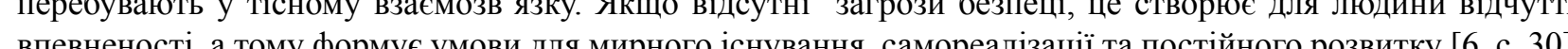

У більшості наукових прашь безпека розглядасться як стан захишеності суспільств іі різого

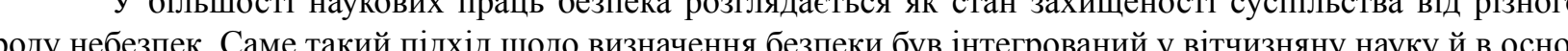
вному першочергово базувався на дослідженнях закордонних вчених (Ж. Абена, Д. Олвея, Дж. Р. Голдена, Р. Келлі, Й. Кукулки).

$\mathrm{y}$ «Глосарії термінів у сфері національної безпеки» термін «національна безпека» визначається як одна з основних сфер функціонування держави, що забезпечує можливість виживання, а також розвитку т свободи реалізаціі національних інтересів у конкретному безпечному середовищі, приймаючи виклики, використовуючи можливості, зменшуючи ризики та протидіючи різним видам загроз [7, с.17]. Як підкреслю-

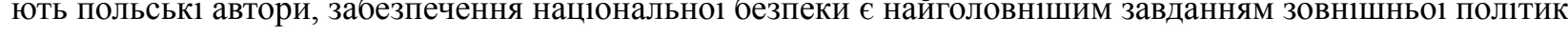
держави, а метою політики національної безпеки є захист держави та суспільства від зовнішніх загроз.

Варто також зазначити, що у традиційному підході до національної безпеки основний акцент робиться на зовнішніх загрозах, але не менш важливим є забезпечення внутрішньоі безпеки. Національн безпека покликана захищати внутрішні цінності кожного суспільства та держави. Згідно з американською школою політичного реалізму, національна безпека $є$ одним із національних інтересів (провідна категорія в цій доктрині); це навіть ототожнюється із існуванням держави та нації, тобто захистом територіально цілісності та політичної незалежності.

Як відомо, термін національна безпека має американське коріння і вперше був введений президентом США Т. Рузвельтом у його політичній заяві Конгресу в 1904 р. Національна безпека в США визначається таким станом суспільства, «при якому Сполучені Штати зберігаються в якості вільної нації та дотримується недоторканність іiї основних інститутів та цінностей» [8, с. 63]. Щодо безпосередньо нормативного закріплення вказаного поняття, то воно відбулося у 1947 р. із прийняттям закону США «Про національну безпеку» (англ. The National Security Act) [9, с. 85]. Варто зауважити, шо американська модель

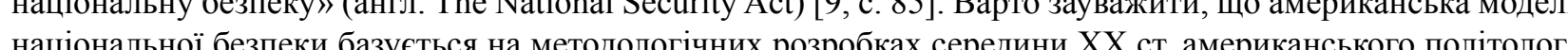
Г. Моргентау, в яких національна безпека розуміється як безпека громадян, суспільства і держави. 
Потреба в безпеці іманентно властива будь-якій системі, а проблеми миру та безпеки стали одними 3 найголовніших стратегічних орієнтирів, що здатні забезпечити прийнятне для розвитку цивілізації, сус3 найголовніших стратегічних орієнтирів, що

Сьогодні серед фахівців існує єдність стосовно того, що національна безпека $є$ досить складним соціально-політичним явищем. Як наголошує Г.Ситник, за своєю суттю це інтегральна багатокомпонентна оцінка наявного (бажаного, прогнозованого) рівня (ступеню) захищеності життево важливих національних інтересів та умов їх реалізації, зокрема, стану соціальноекин інститутів в країні, спроможності національних збройних сил протистояти загрозам територіальній цілісності та незалежності держави тощо [10, с. 118].

О. Гончаренко визначає національну безпеку як категорію, яка характеризує ступінь (міру, рівень) захищеності життєво важливих інтересів, прав та свобод особи, суспільства і держави від зовнішніх і внутрішніх загроз або ступінь відсутності загроз правам і свободам людини, базовим інтересам і цінностям суспільства та держави [11]. В. Ліпкан наголошує, що національна безпека - це «безпека ії народу як носія суверенітету і єдиного джерела влади в Україні» [12]. М. Левицька характеризує національну безпеку як ступінь захищеності особи, держави та суспільства, що забезпечує їх стале функціонування та базується на діяльності особи, суспільства, держави та інших суб'єктів для виявлення, попередження, припинення та ліквідації наслідків загроз національним інтересам [13, с. 12]. Варто зазначити, що вказані підходи до розуміння національної безпеки лише підтверджують той факт, що універсальність змісту національної безпеки визначас універсальність цінностей, які вона відображас.

В розумінні американських, так і інших західних правознавців та політологів «національна безпека це здатність держави зберігати цілісність, суверенність, політичні, економічні, соціальні та інші основи суспільства та виступати в якості самостійного суб'єкта системи міжнародних відносин» [14].

На думку В. Кітлера, національна безпека $\epsilon$ «процесом, що включає різні заходи, що гарантують тривале і вільне існування та національний (державний) розвиток, включаючи захист та оборону держави як політичного інституту, і захист людей та всього суспільства, їхніх благ та природного середовища від загроз, які суттєво обмежують його функціонування або шкодять благам, що підлягають спеціальному захисту» [15, с. 31]. 3 іншого боку, Л. Хойновський вважає, що національна безпека - це впевненість у збереженні найвищих цінностей держави, нації, суспільства та громадян, що $є$ наслідком відсутності загроз або ждатності захищатися від них [16, с. 134].

Як зазначив Р. Врублевський, існування та розвиток є основними фундаментальними цінностями, на які спрямована діяльність кожної держави. Серед них можна виділити п'ять особливих цінностей, які на які спрямована діяльність кожної держави. Серед них можна виділити п'ять особливих цінностей, які
разом утворюють концепцію національної безпеки. Це: суверенітет, територіальна цілісність, національна разом утворюють концепцію національноі безпеки. Це: суверенітет, територіальна цілісність,

3 іншого боку, Р. Земба, розмірковуючи про національну безпеку, зазначає, що «безпека має суб'єктивний характер, i, будучи вищою потребою людини та соціальних груп, вона одночасно є основною потребою держави та міжнародних систем; іії відсутність викликає занепокоєння та відчуття загрози». На думку Р.Зємби, виправданим $є$ введення двох аспектів безпеки: внутрішнього (мається на увазі стабільність даної системи) та зовнішнього (розуміється як відсутність загрози з боку інших суб’єктів) [18, с. 59-60]. Потреба в безпеці обумовлена як внутрішньою структурою суспільства, так і функціонуванням міжнародного середовища, в якому виникають загрози та виклики для цього суспільства.

Безпека розвитку в сучасних умовах має передбачати: збереження власної національно-культурної специфіки, територіальної цілісності, державної самостійності, соціально-політичного ладу, а також - підвищення рівня життя людей і створення умов для розвитку кожного, пропаганду і розширення застосування моральних цінностей, що об єднують громадян різних верств населення і національностей в єдине ціле. Подібний охоронний підхід у визначенні сутності безпеки в суспільстві та національної безпеки, зокрема, переважає і у вітчизняній літературі та інших джерелах. Свідченням цьому є також визначення національної безпеки відповідно до Закону України «Про національну безпеку України», у якому національна безпека України визначасться як захищеність державного суверенітету, територіальної цілісності, демократичного конститущійного ладу та інших національних інтересів України від реальних та потенційних загроз [19]. У свою чергу, нашіональні інтереси України розглядаються в якості життево важливих інтересів людини, суспільства і держави, реалізашія яких забезпечує державний суверенітет України, iї прогресивний демогратичний розвиток, а також безпечні умови життедіяльності і добробут іï громанян.

Варто наголосити, шо державна політика у сферах національної безпеки і оборони спрямована . життедіяльності; суспільства - його демократичних цінностей, добробуту та умов для сталого розвитку; держави - їі конституційного ладу, суверенітету, територіальної цілісності та недоторканності; території, держави - 11 конституційного ладу, суверенітету, територіальноі цілісь

Закон України «Про національну безпеку України» визначас основні принципи порядку формування державної політики у сферах національної безпеки і оборони, а саме:

1) верховенство права, підзвітність, законність, прозорість та дотримання засад демократичного цивільного контролю за функціонуванням сектору безпеки і оборони та застосуванням сили;

2) дотримання норм міжнародного права, участь в інтересах України у міжнародних зусиллях 3 підтримання миру і безпеки, міждержавних системах та механізмах міжнародної колективної безпеки;

3) розвиток сектору безпеки і оборони як основного інструменту реалізації державної політики у сферах національної безпеки і оборони [19].

Вказані принципи державної політики у сфері національної безпеки одночасно виступають ціннісними складовими, правовими векторами подальшого розвитку суспільства.

Фундаментальними національними інтересами України є:

1) державний суверенітет і територіальна цілісність, демократичний конституційний лад, недопущення втручання у внутрішні справи України;

2) сталий розвиток національної економіки, громадянського суспільства і держави для забезпечення зростання рівня та якості життя населення;

3) інтеграція України в європейський політичний, економічний, безпековий, правовий простір, набуття членства в Європейському Союзі та в Організації Північноатлантичного договору, розвиток рівноправних взаємовигідних відносин з іншими державами [19].

На захист національних інтересів України спрямована і Стратегія національної безпеки, положення якої визначають основні напрями державної політики в галузі національної безпеки [20]. У документі також акцентується увага на конституційному положенні, що «людина, іiі життя і здоров’я, честь і гідність, недоторканність і безпека $\epsilon$ найвищою соціальною цінністю в Україні» [21]. Реалізація цієї норми Конституції України $є$ головною метою державної політики національної безпеки і одночасно аксіологічною основою всього національного законодавства.

Аналіз західних і вітчизняних підходів до визначення сутності національної безпеки показуе, що основний акцент в них робиться на захищеності життєвоважливих інтересів особи, суспільства і держави від дії сил, небезпечних для даного суспільства. Мова в них найчастіше йде про інтереси національної безпеки або збереження фундаментальних західних цінностей. Така позиція зумовила тісний взаємозв'язок понять національної безпеки та національних інтересів в їх ціннісно-змістовному наповненні.

Слід зазначити, що термін національна безпека іноді вживається синонімом 3 поняттям державної безпеки. Тим не менше, існує також велика група дослідників, які чітко розрізняють ці терміни. На їх думку, національна безпека є більш ширшим поняттям, ніж державна безпека, і доповнює іії цінностями та потребами, важлвими для особи та різихх соцальни сруп (які с значммими в демократичній правовій державі, такі як громадянські права та свободи, захист населення, довкілля та національної спадщини) [18, c. 60].

Висновки. Таким чином, проблеми національної безпеки відносяться до числа найважливіших i найскладніших проблем сучасності. У сучасних умовах істотно зріс ризик терористичних, політичних, економічних та екологічних загроз, негативні наслідки яких можуть торкнутися і України, навіть якщо вони виникли в іншій країні. Саме тому, усвідомлення загроз дозволить належним чином підготуватися до їх усунення. Правові норми щодо усунення загроз та підтримання національної безпеки полягають в першу чергу у визначенні того, які сили та ресурси слід використовувати у випадках конкретних загроз та якими є компетенції кожної інституції, відповідальної за підтримку безпеки. Безпека завжди є метою. Саме тому, Україна потребує ефективної системи національної безпеки, що грунтувалась би на визнанні примату загальнолюдських цінностей і прав особи, органічному узгодженні з ними базових інтересів незалежно України. Як зазначає О.Власюк, ії побудова потребує грунтовного аналізу теоретичних проблем безпеки, синтезу конкретних форм і методів ії забезпечення, узагальнення та засвоєння досвіду функціонування систем безпеки розвинених країн світу і міжнародних систем колективної безпеки, розроблення наукової коншепнії нащіональної безпеки України [3, с.23]. Нашіональна безпека включає в себе оборону держави і всі види безпеки, передбачені Конституй с всі гіл ін, інормаційну, екологічну, економічну, транспортну, енергетичну безпеку, безпеку особжстості. Це особливий стан захищеності особи, суспільства і держави від внутрішніх і зовнішніх загроз, при якому 
забезпечуються реалізація конституційних праві свобод громадян, гідні якість і рівень їх життя, суверені-

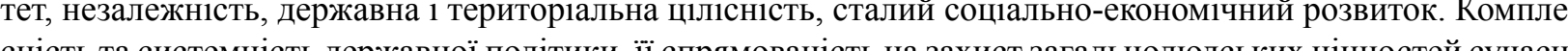
цивілізації має стати запорукою подальшого розвитку нашого суспільства.

\section{Список використаних джерел}

1. Глобальна та національна безпека: підручник / авт. кол. : В.І. Абрамов, Г.П.Ситник, В.Ф. Смолянюк та ін. / за заг. ред. Г.П.Ситника. Київ : НАДУ, 2016. 784 с.

2. Копанчук В.О. Онтологічно-гносеологічний механізм забезпечення національної безпеки України: філософський аспект. Вісник Національного університету иивільного захисту України. 2017. Випуск 6. URL: https://nuczu.edu.ua/.../Visnik NUCZU 1\%20(6) 2017 Kopanchuk.pdf (дата звернення: 12.02.2021).

3. Власюк О. С. Національна безпека України: еволюція проблем внутрішньої політики : Вибр. наук. праці. К. : НІСД, 2016. 528 c.

4. Мартиненко В. В. Еволюція теоретичних підходів до визначення понять «національна безпека» та «економічна безпека». Концептуальні засади економічного і правового забезпечення безпеки держав в умовах євроінтеграції: матер. міжнар. наук.-практ. конф., Одеса-Черкаси, 28-29 квітня 2015 р./ Мінво освіти і науки України, Мін-во внутрішніх справ України, Одеський держ. ун-т внутрішніх справ [та ін.]. Одеса, 2015. С. 56-58.

5. Основы экономической безопасности: (Государство, регион, предприятие, личность) : [учебно-практическое пособие] / В.И. Видяпин [и др.]; ред. Е.А Олейников ; Российская экономическая академия им. Г.В. Плеханова (М.). М. : Бизнес-школа Интел-Синтез, 1997. 279 с.

6. Lis W. Bezpieczeństwo wewnętrzne i porządek publiczny jako sfera działania administracji publicznej, Lublin:Wydawnictwo KUL, 2015. $495 \mathrm{~s}$.

7. Słownik terminów z zakresu bezpieczeństwa narodowego. Pod kierownictwem d-ra hab. inż. Bogdana Zdrodowskiego. Warszawa: Wydawnictwo Akademii Obrony Narodowej. Wydział Strategiczno-Obronny, 2008. 182 s. URL: https://docplayer.pl/1120197-Akademia-obrony-narodowej-wydzial-strategicznoobronny-slownik-terminow-z-zakresu-bezpieczenstwa-narodowego.html

8. Алексин В.И. Советско-американское военное сотрудничество: контакты и осмысление их результатов. Военная мысль. 1992. № 3. С. 63.

9. Павлютін Ю. М. Система нашіональної безпеки: політико-правовий аналіз. Честь і закон. 2020. № 3. C. 84-90. URL: http://nbuv.gov.ua/UJRN/Chiz_2020_3_14

10. Ситник Г.П. Державне управління у сфері національної безпеки (концептуальні та організаційно-правові засади): Підручник К.: НАДУ, 2011. 730 с.

11. Гончаренко О.М., Лисицин Е.М., Вагапов В.Б. Поняття національної безпеки в контексті національних інтересів України. Наука і оборона. 2002. №1. С. 18-24.

12. Ліпкан В.А. Теорія національної безпеки: підручник. К. : КHT, 2009. 576 c. URL: http://politics.ellib.org. ua/pages-cat-154.html

13. Левицька М.Б. Теоретико-правові аспекти забезпечення національної безпеки органами внутрішніх справ України : автореф. дис. ... канд. юрид. наук: 12.00.01; НАН України. Ін-т держави і права ім. В.М. Корецького. К., 2002. 17 с.

14. Анохин Ю., Гадельшин Р. Национальная безопасность: теоретические и терминологические аспекть Теория и практика общественного развития. 2017. № 12. С. 126-129. URL: https://cyberleninka.ru/ article/n/natsionalnaya-bezopasnost-teoreticheskie-i-terminologicheskie-aspekty/viewer (дата звернення: 12.02.2021)

15. Kitler W. Bezpieczeństwo narodowe RP: podstawowe kategorie, uwarunkowania, system. Warszawa, Wydawnictwo Akademii Obrony Narodowej, $411 \mathrm{~s}$.

16. Chojnowski L. Bezpieczeństwo narodowe. Studium teoretyczne. Wydawnictwo Naukowe Akademi Pomorskiej w Stupsku, Słupsk. $2016.272 \mathrm{~s}$

17. Wróblewski R. Wprowadzenie do nauk o bezpieczeństwie, Siedlce, Uniwersytet Przyrodniczo-Humanistyczny w Siedlcach, 2017. s. 120.

18. Kamiński Mariusz Antoni. Prawo bezpieczeństwa narodowego. Wiedza obronna. 2019. Vol. 268. № 3. S. 5775. URL: http://wiedzaobronna.edu.pl/index.php/wo/article/view/2 (дата звернення: 12.02.2021).

$\overline{16}$

ISSN 2524-0129 (Print)//SSN (2664-5718) (Online). Актуапьні проблеми правознавства. 1 (25)/2021
19. Про національну безпеку України. Закон України від 21 червня 2018 року №2469-VII. URL: https:// zakon.rada.gov.ua/laws/show/2469-19\#Text

20. Про рішення Рали нашіональної безпеки і оборони України віл 14 вересня 2020 року «Про Стратегію національної безпеки України». Указ Президента України №392/2020 14 вересня 2020 року. URL https://www.president.gov.ua/documents/3922020-35037 (дата звернення: 15.02.2021)

21. Конституція України від 28 червня 1996 року. Документ 254к/96-ВР. Редакція від 01.01.2020 року, підстава - 27-IX. URL: https://zakon.rada.gov.ua/laws/show/254\%D0\%BA/96-D0\%B2\%D1\%80\#Text (дата звернення: 12.02.2021).

\section{References}

1. Abramov, V.I., Sytny, H.P. \& Smolianiuk V.F. (2016). Hlobalna ta natsionalna bezpeka [Global and national security]. Kyiv: NADU [in Ukrainian].

2. Kopanchuk, V.O. (2017). Ontolohichno-hnoseolohichnyi mekhanizm zabezpechennia natsionalnoi bezpeky Ukrainy: filosofskyi aspect [Ontological and epistemological mechanism of national security of Ukraine: philosophical aspect]. VisnykNatsionalnoho universytetu tsyvilnohozakhystu Ukrainy-Bulletin of the Nationa University of Civil Defense of Ukraine, 6. Retrieved from https://nuczu.edu.ua/.../Visnik_NUCZU_1\%20 (6)_2017_Kopanchuk.pdf [in Ukrainian].

3. Vlasiuk, O. S. (2016). Natsionalna bezpeka Ukrainy: evoliutsiia problem vnutrishnoi polityky : Vybr. nauk pratsi [National Security of Ukraine: Evolution of Domestic Policy Problems]. Kyiv: NISD [inUkrainian].

4. Martynenko, V. V. (2015). Evoliutsiia teoretychnykh pidkhodiv do vyznachennia poniat «natsionalna bezpeka ta «ekonomichna bezpeka». [Evolution of theoretical approaches to the definition of ,national security" and «economic security»]. Kontseptualni zasady ekonomichnoho I pravovoho zabezpechennia bezpeky derzhavy v umovakh yevrointehratsii - Conceptual principles of economic and legal security of the state in the condition of European integration: Proceedings of the International Scientific and Practical Conference (pp. 56-58). Odesa [in Ukrainian].

5. Vydiapyn, V.Y. (1997). Osnovy ekonomicheskoi bezopasnosti [Basics of economic security]. Moscow: Byznes-shkolaYntel-Syntez [in Russian].

6. Lis, W. (2015). Vnutrishnia bezpeka ta hromadskyi poriadok yak sfera diialnosti derzhavnoho upravlinnia [Internal security and public order as the sphere of public administration activities]. Lublin: Wydawnictwo KUL [in Poland].

7. Zdrodowski, B. (2008). Slovnyk terminiv u haluzi natsionalnoi bezpeky [Glossary of terms in the field Zf national security]. Varshava: Vydaunytsvo Natsion of national B. stract//docplayer.pl/1120197-Akademia-obrony[in Poland].

. Oleksyn, V.I. (1992). Radiansko-amerykanske viiskove spivrobitnytstvo: kontakty I osmyslenniay ikh rezultativ [Soviet-American military cooperation: contacts and understanding their results]. Voennaia mysl Military thought. 3, 63 [in Russian].

9. Pavliutin, Yu. M. (2020). Systema natsionalnoi bezpeky: polityko-pravovyi analiz [National security system political and legal analysis]. Chest $i$ zakon - Honor and law. Retrieved from http://nbuv.gov.ua/UJRN/ Chiz_2020_3_14 [in Ukrainian].

10. Sytnyk, H.P. (2011). Derzhavne upravlinnia u sferi natsionalnoi bezpeky (kontseptualni ta orhanizatsiinopravovi zasady) [Public administration in the field of national security (conceptual and organizational and legal principles)]. Kyiv: NADU [in Ukrainian].

1. Honcharenko, O.M., Lysytsyn, E.M. \& Vahapov, V.B. (2002). Poniattianatsionalnoi bezpeky v kontekst natsionalnykh interesiv Ukrainy [The concept of national security in the context of national interests of Ukraine]. Nauka i oborona - Science and defense, 1, 18-24. [in Ukrainian].

12. Lipkan, V.A. (2009). Teoriia natsionalnoi bezpeky : pidruchnyk [Theory of national security]. Kyiv : KNT. Retrieved from http://politics.ellib.org.ua/pages-cat-154.html [in Ukrainian].

13. Levytska, M. B. (2002). Teoretyko-pravovi aspekty zabezpechennia natsionalnoi bezpeky orhanamy vnutrishnikh sprav Ukrainy [Theoretical and legal aspects of ensuring national security by the internal affairs bodies of Ukraine]. Extended abstract of candidate's thesis. NAN Ukrainy. In-t derzhavy i prava im. V.M. Koretskoho. Kyiv [in Ukrainian]. 
14. Anohin, Yu. \& Hadelshyn, R. (2011). Natsionalnaya bezopasnost: teoreticheskie i terminologicheskie aspekty [National security: theoretical and terminological aspects]. Teoryia i praktyka obshchestvennoho razvytiya Theory and practice of social development, 12, 126-129.

15. Kitler, W. (2011). Bezpieczeństwo narodowe RP: podstawowe kategorie, uwarunkowania, system [National security of the Republic of Poland: basic categories, conditions, system]. Varshava, Wydawnictwo Akademi Obrony Narodowej [in Poland].

16. Chojnowski, L. (2016). Bezpieczenstwo narodowe. Studium teoretyczne [National security. Theoretical study]. Wydawnictwo Naukowe Akademii Pomorskiej w Sllupsku, Slłupsk [in Poland]

7. Wrublewski, R. (2017). Wprowadzenie do nauk o bezpieczenstwie [Introduction to safety science]. Siedlce, Uniwersytet Przyrodniczo-Humanistyczny w Siedlcach [in Poland].

8. Kaminski, Mariusz Antoni (2019). Prawo bezpieczenstwa narodowego [National security law]. Wiedza obronna - Defense knowledge, 3, 57-75. Retrieved from http://wiedzaobronna.edu.pl/index.php/wo/article/ view/2 [in Poland].

19. Pro natsionalnu bezpeku Ukrainy. Zakon Ukrainy vid 21 chervnia 2018 roku №2469-VII. [On the national security of Ukraine. Law of Ukraine of June 21, 2018 №2469-VII]. Retrieved from https://zakon.rada.gov.ua laws/show/2469-19\#Text [in Ukrainian].

20. Pro rishennia Rady natsionalnoi bezpeky i oborony Ukrainy vid 14 veresnia 2020 roku «Pro Stratehiiu natsionalnoi bezpeky Ukrainy». Ukaz Prezydenta Ukrainy №392/2020 14 veresnia 2020 roku. (On the decision of the National Security and Defense Council of Ukraine of September 14, 2020 „On the National Security Strategy of Ukraine”. Decree of the President of Ukraine №392 / 2020 September 14, 2020.]. Retrieved from https://www.president.gov.ua/documents/3922020-35037 [in Ukrainian].

21. Konstytutsiia Ukrainy vid 28 chervnia 1996 roku. Dokument 254k/96-VR. Redaktsiia vid 01.01.2020 roku, pidstava [Constitution of Ukraine of June 28, 1996. Document 254k/ 96-BP. Edition from 01.01.2020, basis 27-IX]. Retrieved from https://zakon.rada.gov.ua/laws/show/254\%D0\%BA/96-\%D0\%B2\%D1\%80\#Text [in Ukrainian].

Стаття надійшла до редакшії 27.02.2021.
DOI:10.35774/app2021.01.019

УДК 347.965 .42

\section{Наталія Фігун,}

\section{магістр права, стипендистка}

пост-магістерської програми

Міжнародного Вищеградського Фонду,

нститут соиіальної профілактики $i$

ресоиіалізаиї̈, Варшавський університеп,

Республіка Польща

ORCID: https://orcid.org/0000-0003-2842-1926

- Visegrad Fund

$$
\text { - }
$$

\section{СТАНОВЛЕННЯ ІНСТИТУТУ МЕДІАЦІЇ У КРАЇНАХ}

\section{ВИШЕГРАДСЬКОЇ ГРУПИ}

Здійснено аналіз прочесу розвитку інституту медіаиї̈ у країнах Вишеградської групи - Польщі, Чехї

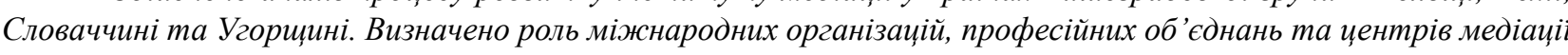
у прочесі становлення та популяризаиії медіації. Проаналізовано особливості правового регулювання медіаиії у законодавстві досліджуваних країн. На підставі дослідження виокремлено умовні етапи проиесу імплементачії медіаиії до правових систем країн та основні передумови цього прочесу.

Ключові слова: альтернативні способи вирімення спорів, медіачія, імплементаиія медіаиії, медіатор, об'єднання медіаторів, медіаиія у країнах Вишеградської групи.

Бібл.: 27.

\section{Фигун $\boldsymbol{H}$.}

Становление института медиации в странах Выщеградской группь

Осуществлен анализ прочесса развития института медиаиии в странах Вышеградской группь- -Польме, Чехии, Словакии и Венгрии. Определена роль международных организаций, профессиональных объединений и центров медиации в проиессе становления и популяризации медиации. Проанализированы особенности пра вового регулирования медиации в законодательстве исследуемых стран. На основании исследования выделены условные этапы прочесса имплементации медиации в правовые системы стран и основные предпосылки этого проиесса.

Ключевые слова: альтернативные способы разремения споров, медиаия, имплементачия медиачии медиатор, объединения медиаторов, медиаџия в странах Вымеградской групиы.

\section{Fihun $N$.}

Establishment of the institute of mediation in the Visegrad Group countries

In Slovakia, the Czech Republic, Hungary, and Poland, the development of alternative dispute resolution and the first attempts at mediation took place in the early 1990s, and the legal framework and organizations providing mediation services are still in place. As the process of institutionalization of the mediation procedure is still ongoing in Ukraine, it is important to analyze the experience of other countries in implementing mediation in their legal systems. The aim of the article is to analyze the process of formation of the mediation institution in Slovakia, the Czech Republic,
Poland, and Hungary. The article descr.

Visegrad Group, in particular the in of international parthers in the development of the mediation institution in the Visegrad Group, in particular the international organization Partners for Democratic Change, which facilitated the establish Gen of mediation centers in the counties, conduct Padition the contribution of projects. In addition, the contribution of mediation centers and professional associations of mediators in the development ' Стаття написана та видана в рамках реалізації наукового проєкту «Процедура медіації в країнах Вишеградської групи: досвід для України» («Mediation procedure in the Visegrad Group countries: experience for Ukraine»), фінансованого МіжнародНим Вишеградським $\Phi$ 